\title{
Aesthetics of Enumeration: The Arma Christi in Medieval Visual Art
}

\author{
Daniela Wagner
}

On fol. 331r of the Prayer Book of Bonne of Luxembourg, ${ }^{1}$ we find a representation that almost forces us to reflect upon the practice of enumeration as it illustrates a sophisticated conceptual understanding of the list in visual art (Fig. 12.1): thirteen objects known as the Arma Christi are gathered in the central space of the small page of only $12.6 \times 9 \mathrm{~cm}$. All of them are of importance in the narrative of the Passion. The collection is dominated by the centrally placed side wound, which measures the full height of the picture space. ${ }^{2}$ To its left, we see the hammer, the rod with the sponge, the cross with the crown of thorns, the lance, and the empty sarcophagus. To the right are three nails, two scourges, the bucket, the flagellation column with the rope wrapped around it, and the pincers. In comparison with the other objects, the size of the side wound indicates already that the aim here was not to achieve authentic proportions. The

Funded by the Deutsche Forschungsgemeinschaft (DFG, German Research Foundation)-Project-ID 405662736-SFB 1391.

D. Wagner $(\bowtie)$

University of Tübingen, Tübingen, Germany

e-mail: daniela.wagner@uni-tuebingen.de

(C) The Author(s) 2022

R. A. Barton et al. (eds.), Forms of List-Making: Epistemic, Literary, and Visual Enumeration, https://doi.org/10.1007/978-3-030-76970-3_12 


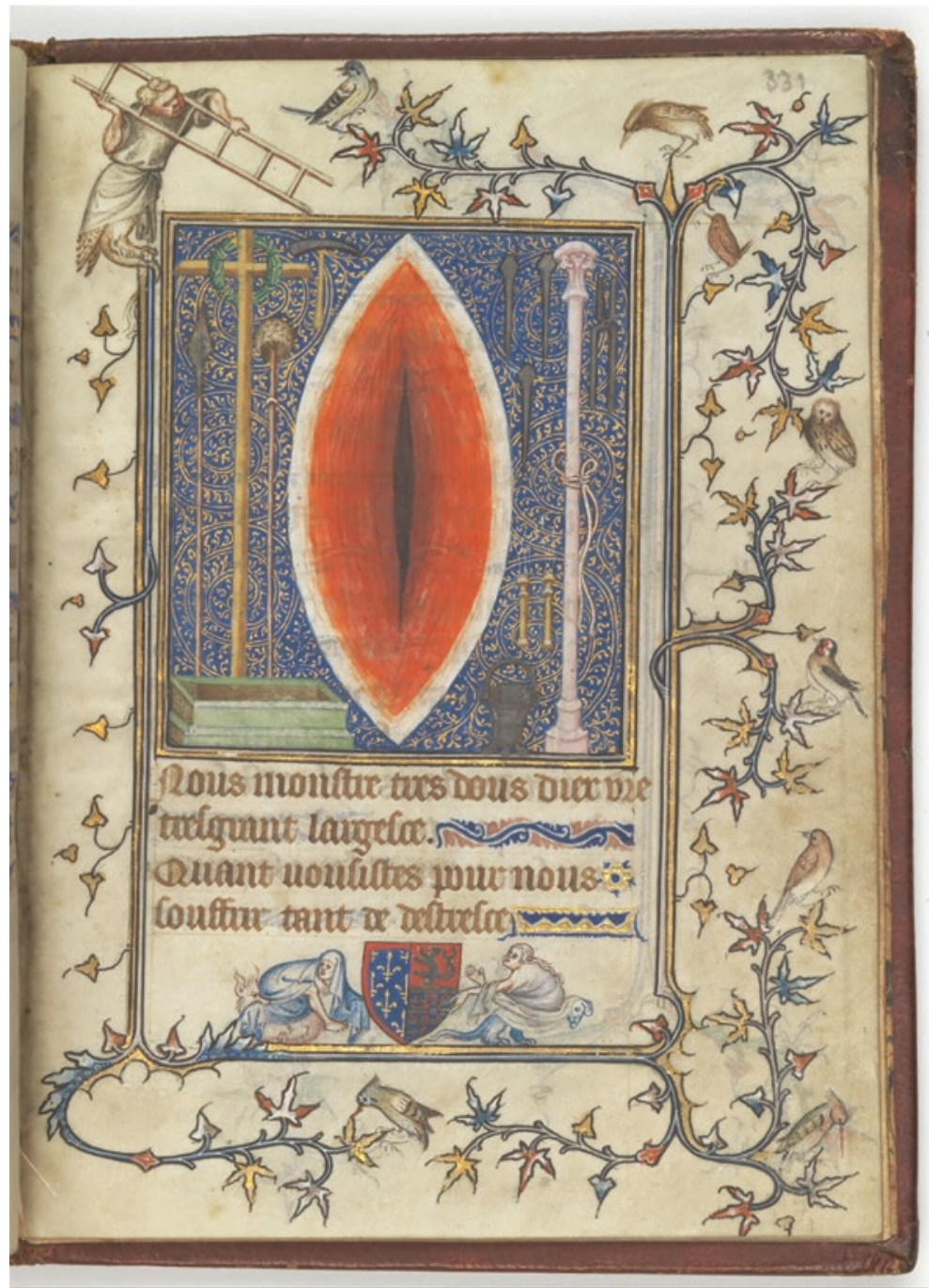

Fig. 12.1 Prayer Book of Bonne of Luxemburg, Paris, before 1349, Metropolitan Museum, New York, The Cloisters Collection, accession number 69.86, fol. $331 \mathrm{r}$ 
highlighting of the side wound is based on the hierarchy of meanings. As the wound that makes the body of Christ accessible to the faithful, it is the most significant of all the items gathered here. ${ }^{3}$ Below the picture, a French text initiates a dialogue between Christ and the reader-viewer by referring to the violence performed with the Arma, the instruments of the Passion: "Show us, sweet Lord, your greatest goodness. How great was the suffering you bore for our sakes?" 4

The text, the picture space, and the bas de page with grotesques holding the coat of arms of Bonne of Luxembourg are surrounded by a strip frame, which is left open at the top. Thorn-leaf tendrils with various birds ${ }^{5}$ sitting on them are sprouting from this frame and spread along the margins. Of interest for the Arma Christi and the practice of enumeration, however, is the ladder that is laboriously handled by a hybrid creature of man and mythical beast, which is balancing at the outside edge of the frame's strip on the top left. His neck pushed through the rungs and a hand on each rail, he allows one foot of the ladder to rest casually on the frame of the Arma image.

On the page and in the context of the preceding pictorial program, the ladder turns out to be a figure of reflection open to interpretation. It has been seen as an ironic reference to the ascent of the soul, which is symbolized by a ladder, and also was understood as a reference to the six stages of divine love depicted on fol. 315r of the prayer book (Tammen 2006, 98). Along with fol. $315 \mathrm{r}$ and the miniature of a couple looking up at Christ's cross on fol. 329r, the ladder has also been interpreted as a part of the visualization of a spiritual pilgrimage (Lermack 2008). In addition to these allegorical readings, however, the connection between the ladder and the Arma Christi would have been most obvious to late medieval beholders, as the ladder is known from the deposition of Christ and often can be found among the Arma Christi in texts and images. On fol. 331r, it remains separate from the objects arranged in the picture space, but the hybrid creature apparently endeavors to move the ladder into this space to complement the Arma already assembled there.

This playful device, which interweaves the levels of composition and content,${ }^{6}$ invites viewers to complete the action in their minds and involves them in the process of enumeration. The artist, possibly Jean le Noir, to whom the book is ascribed, reflects first of all on the character of the Arma Christi as an enumeration, but also the openness of the motif and the term. "Arma Christi" does not mean all the objects involved in the Passion, nor does it refer to a fixed group of instruments of the Passion. "Arma 
Christi" is a collective term allowing no conclusions to be drawn about which objects are actually included in the list. The possibilities of what a set of the Arma Christi could contain are defined roughly by the context of the Passion narrative, but without providing further specifications.

The objects gathered on fol. 33Ir of the Prayer Book of Bonne thus are a representation of the Arma Christi either way, with and without the ladder. A fixed unit is established only on an individual basis for each spoken, textual, or visual combination. But when the ladder is brought in to complete the set of instruments within the frame, the pictorial list obtains a liminal state-it is as complete as it is incomplete-and thus is captured in the process of change. With the figure holding the ladder, the painter reflects on the productive aspect of creating a list, as an enumeration of the Arma Christi in text or image is the outcome of a two-stage process: the selection of the elements to be included is followed in a second step by their specific arrangement.

Robert Belknap has described literary lists as "adaptable containers that hold information from the mind-deep pool of possibility" $(2000,39)$, and this can also be applied to the highly variable visual representations of the Arma Christi. ${ }^{7}$ The diversity and flexibility of pictorial enumerations of the Arma apply to two levels, to that of content and that of form, reflected in the aforementioned aspects of selection and arrangement. Although the production process is rarely visualized as explicitly as it is in the Prayer Book of Bonne of Luxembourg, pictorial representations of the Arma Christi consistently reveal an explicit consideration of aesthetic questions, especially regarding the structuring of enumeration. Just as no fixed set of objects has been established as "the" Arma Christi, no binding representational system was ever consolidated on the formal level, either. Thus, in addition to depictions such as the one in the Prayer Book of Bonne of Luxembourg, which operates with size hierarchies and presents an "orderly," easily comprehensible arrangement, other depictions of the Arma take the forms of irregular scatterings, accumulations, grid structures, or linear and circular sequences. ${ }^{8}$ The fact that one representation rarely resembles another indicates that for each work a new list was created and configured individually in visual terms. Over and over again, artists and/or clients considered the selection of objects and their arrangement anew and were thoughtfully merging the content of the list and its appearance. ${ }^{9}$

It is precisely due to this heterogeneity of combinations and their structures that the Arma Christi are a motif capable of shedding light on the 
constitution and functionality of pictorial enumerations when studied under the premise of its list-like character. As will be shown, in pictorial enumerations of the Arma Christi aesthetic and functional aspects are inseparably intertwined and relate to each other repeatedly in a productive way regarding the creation of meaning and the involvement of the beholder. The particular importance ascribed to aesthetics becomes apparent in the various visual reflections on the list and its characteristics in medieval art. Moments of reflection like the one in the Bonne prayer book allow us to discern an artistic awareness of the enumeratio as a figure of visual rhetoric. ${ }^{10}$ Therefore, the following explorations should also present an approach to a more theoretical understanding of enumeration in visual art.

So far, enumeration and lists have been discussed primarily in literary studies. ${ }^{11}$ Recent literary research in particular has provided a theoretical understanding of the list, which is now considered as such primarily because of its organizational structure and not due to a specific visual appearance. ${ }^{12}$ The term "list," therefore, is applicable when three or more distinct units (words or groups of words) are arranged in a row as well as when they are placed one below the other in columns. This definition can also be used in visual art, in which ordering structures are more diverse. An identification of enumerations and lists with a specific type of appearance, therefore, seems to make very little sense in this case. Often, there is no difference made between the terms "enumeration" and "list." A distinction, however, seems to be useful in general, but especially for the approach suggested in this chapter, in which the practice of enumeration and its product are treated as separate aspects. In the following, "list" refers to the result of the process of selection and arrangement, while "enumeration" is used to address the practice and the process of listmaking through selection and arrangement.

\section{Meanings}

In early medieval visual art, the Arma Christi function as signs of triumph and majesty, especially when they appear alongside Christ enthroned or the Lamb of God. Based on the surviving artworks, it is impossible to say whether the Arma could already be found as an independent motif in those times; however, there exist various, well-known early Christian texts in which they serve as a starting point for religious contemplation. ${ }^{13}$ It is therefore likely that the Arma existed as an independent pictorial motif 
significantly earlier than generally assumed. In their meaning as a sign of triumph, the Arma refer to the victory of Christ-like trophies, which is sometimes visualized with recourse to the ancient tropaion, a rack displaying the captured weapons of a defeated enemy. ${ }^{14}$ The tropaion motif is echoed in the Prayer Book of Bonne with the crown of thorns hung on the cross. It is more obvious, however, in the drawing of the Utrecht Psalter, which is regarded as one of the earliest known independent depictions of the Arma Christi (Fig. 12.2). ${ }^{15}$ On fol. 12r, the objects attached to the cross or positioned close to it (scourge, the crown of thorns, lance, the sponge rod, and two other items that cannot be identified clearly) refer to the 21 st Psalm. ${ }^{16}$ The objects form a cluster or accumulation which emphasizes the close connection between the individual elements. In their agglomeration in the Utrecht Psalter, the items are recognizable as a unit and function as such. They allude to the sufferings of Christ culminating in the crucifixion, but through the reference to the tropaion they also are reminders of the victorious triumph over his suffering. ${ }^{17}$ In her studies on the mentions of the Arma Christi in early Christian texts, Mary Agnes Edsall has pointed out the rhetorical figure of accumulatio often used there (see 2014a). It can be assumed that this list-like quality of the Arma in texts, among others by highly regarded authors such as Augustine, also influenced the enumeratio of the Arma in visual art. Like the tropaion

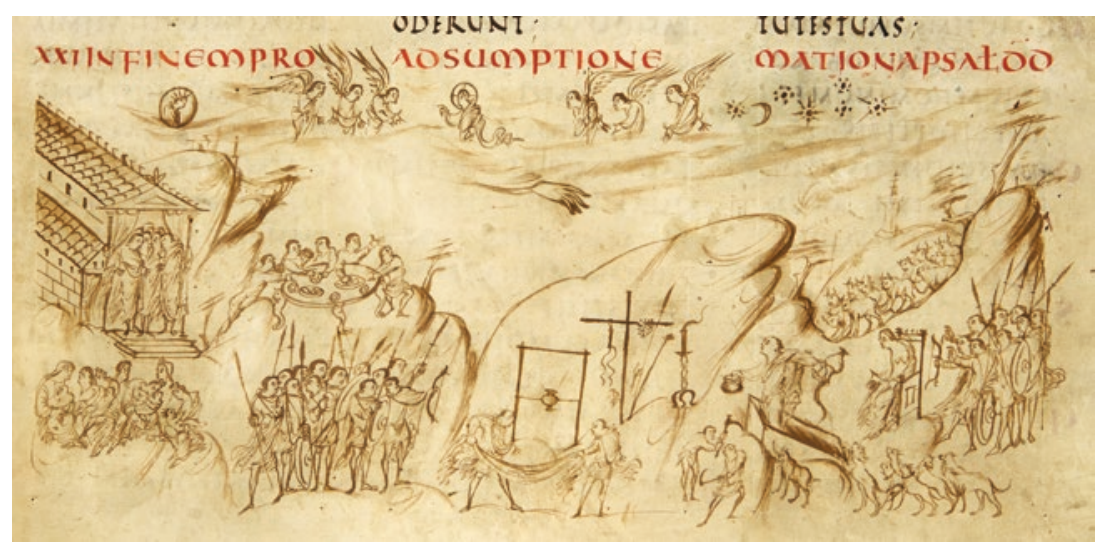

Fig. 12.2 Utrecht Psalter, area of Reims, probably 820-830, Universiteitsbibliotheek Utrecht, Ms. 32, fol. 12r, image credits: Universiteitsbibliotheek Utrecht 
motif, some of the text passages quoted by Edsall are also characterized by the notion of victory: in the Acts of Thomas, for example, the objects and actions that cause suffering (such as being spit on) function as a support for the Christian in his struggle against the devil or for receiving divine grace (Edsall 2014a, 31-32).

The shift in Christ's perception from glorious ruler to the incarnate Savior, the emergence of Passion piety, and a turn toward the suffering of Jesus in worship, prayer, and devotion were accompanied with a change in the very notion of the Arma Christi in the twelfth century: they were integrated into the meditation on the Passion. In this context, the Arma are no longer imagined as signs of victory but as those objects and actions that inflicted mental and physical suffering on Christ. In the context of the private practice of piety, images of the instruments of the Passion became useful for religious contemplation and compassion. This new functionality of the motif in the late Middle Ages becomes visible in the vital artifacts of private devotion, texts, and images. Henceforth, the Arma have frequently appeared in prayer texts and books, small-format panel paintings, and, from the fifteenth century onward, in single-sheet prints and devotional booklets. However, the meaning of the Arma as symbols of victory did not disappear entirely; their visual accentuation as signs of triumph or instruments of the Passion still depended on the individual representation. One meaning did not always exclude the other; composition and context provide indications of the intended reading. Furthermore, the apotropaic power attributed to the Arma Christi ${ }^{18}$ and the indulgence that could be obtained through them suggest a connection to the imagination of victory and the overcoming of suffering.

\section{Narration ANd EnUmeration}

Despite their shared origins, a different functionality was ascribed to the events of the Passion in narrative images and the enumeration of the Arma Christi, which can be illustrated using the example of an ivory picture booklet made in the second quarter of the fourteenth century (Figs. 12.3a and b). ${ }^{19}$ Between the ivory book covers, which are decorated with carved scenes, there are six thin plates, also made of ivory, whose depictions are not carved but painted. The first pages each show a scene from the Passion, followed by the sequence of the instruments of the Passion starting on the recto page of the fifth panel with a full-page depiction of the Vera Icon. The list continues on the verso side with the hand that struck Christ at the 

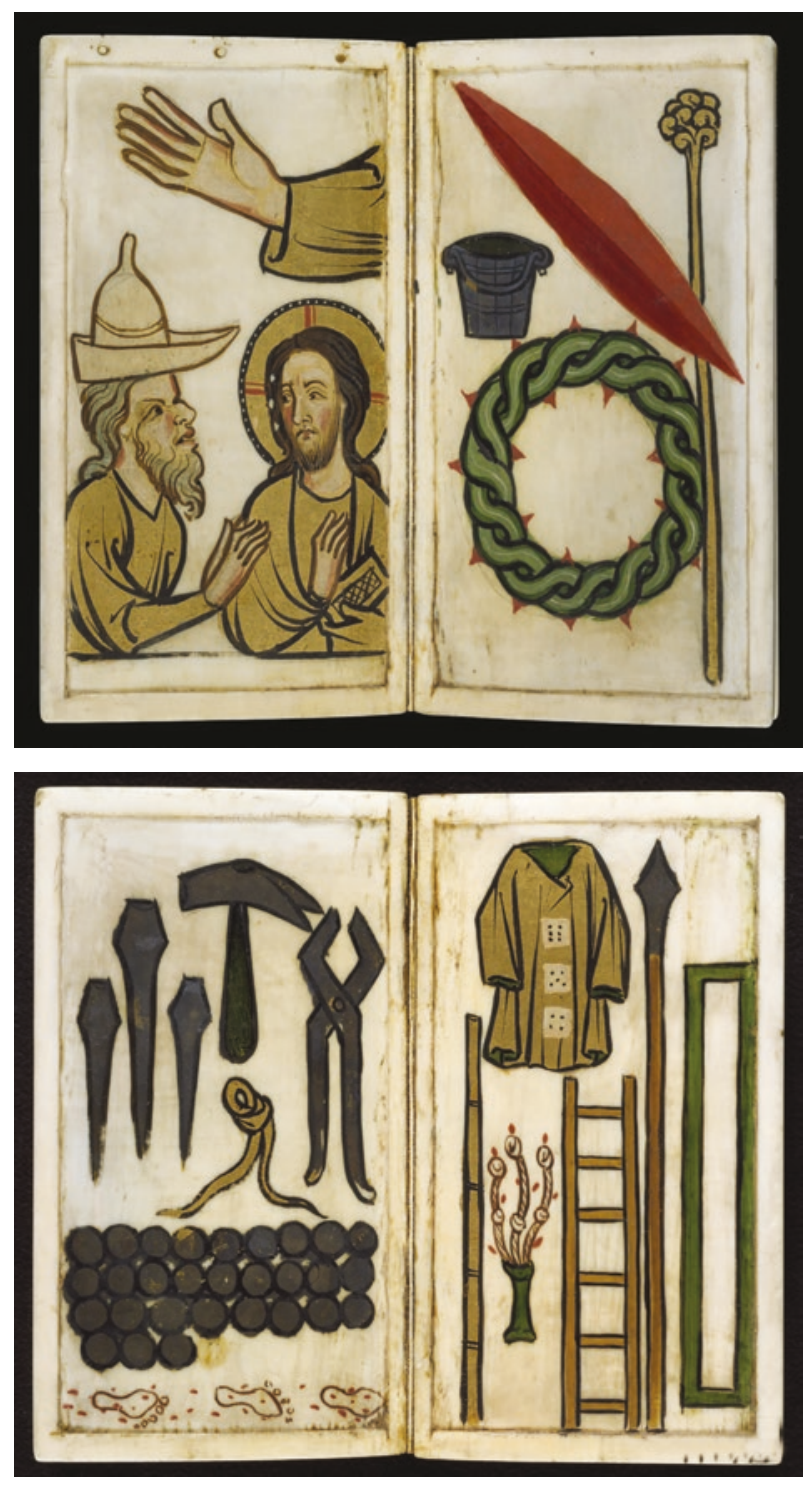

Fig. 12.3 (a, b) Ivory booklet with scenes of the Passion and the Arma Christi, ca. 1330-1340, Victoria and Albert Museum, London, Museum number 11-1872, $5 \mathrm{v}-7 \mathrm{r}$, (C) Victoria and Albert Museum, London 
top and Christ with one of his tormentors below. ${ }^{20}$ Opposite, on the recto side of the sixth inner panel, the bucket, the side wound, the sponge rod, and the crown of thorns are presented. On the next double page, three nails, the hammer, pincers, the blindfold, the thirty pieces of silver, and blood-stained footprints of Christ are shown on the left, while the staff of reed, the robe and three dice, the scourge, the ladder, the lance, and the sarcophagus (seen from above) are positioned on the right on the inside of the booklet's back cover.

Concerning the arrangement, it is striking how sequence and accumulation coincide in this booklet and form a discernible contrast: the scenes of the Passion are aligned one after another, and as the turning of the pages is required to advance within the narrative, a linear reading is stipulated. While it is also necessary to turn the pages to see the Arma Christi in their entirety, the mode of organization changes after the introductory full-page picture of the Vera Icon. From this point on, each page shows several individual elements, which are no longer arranged in a row like the narrative images. Although the page with the hand and the Christ-group still suggests a direction from top to bottom, on the opposite page we find a disordered accumulation with no obvious reading direction. Unlike in the Prayer Book of Bonne, there is no central element directing the gaze here; a hierarchical or compositional center does not exist. The same applies to the following double page. Here, long and narrow objects are positioned adjacently, and nails, the hammer, and pincers (the tools used in the nailing to and in the deposition from the cross) as well as the dice ${ }^{21}$ and Christ's robe form units, but it is impossible to spot distinct chronological, hierarchical, or narrative structures. Further, the semblance of order is alluded to even as it is denied: nails, the hammer, and pincers might be read from left to right, but since the hammer in the middle projects above the items to its sides and takes a higher position, the horizontal reading direction is interrupted and challenged by the vertical. Since the booklet begins with a chronologically linear narrative, the deliberate disorder in the second part is even more striking.

It becomes clear that the two modes of organization offer the viewer different approaches for contemplating Christ's suffering. In the ivory booklet, the artist acknowledged the functionality of narration and enumeration and made use of it to offer the beholder multiple ways for contemplation. ${ }^{22}$ While the former allows the events to continuously move toward the climax of salvation history, the latter obstructs an integration into the linear narrative scheme. Through their detachment from the 
Passion narrative and their establishment as an independent motif, the Arma provide access to the Passion by means of the materiality and agency of things. ${ }^{23}$ In narrative sequences of the Passion, the steadily increasing agony of Christ is paralleled with the intensifying acts of violence against his soul and body. With the Arma Christi, however, the observer does not see the harmed body of Christ in repetition but beholds the various objects (and sometimes people) related to Christ which cause him suffering. Contemplatio and compassio thus are activated by the instruments of violence rather than by their victim. ${ }^{24}$

This aspect of refocusing on the objects is already linked to the structural character of the Arma as an enumeration. Through their enumeration, the individual instruments are removed from the context of the narrative, and a list is created. And yet another effect arises: the enumerated elements separated from the narration are fanned out and achieve heightened visibility. In other words, the readers' or viewers' perception is reconfigured and directed toward supposedly trivial or secondary matters. Wolfgang Schmidgen has described this process of moving-into-sight using the example of lists in Daniel Defoe's Robinson Crusoe. ${ }^{25} \mathrm{He}$ describes how things rather ordinary on the ship_- "two or three bags of nails and spikes, a great skrew-jack, a dozen or two of hatchets, and above all, that most useful thing called a grindstone" (Defoe 1985, 72-72, qtd. in Schmidgen 2001, 21) - are granted special attention after being salvaged from the wreck and enumerated. Unlike this case, however, the Arma Christi are not a list already drawn up in the Passion narrative; each individual Arma-enumeration only originates in the treatment of the theme. Despite the detachment, the Passion is maintained as a context and as the source of the Arma. In other words, while outside of the novel Robinson's list would not reveal that the objects were recovered from a shipwreck, the Arma Christi ran no risk of being misunderstood as anything else by contemporary Christian observers. ${ }^{26}$

\section{Lists and the Practice of Piety}

It seems that precisely the combination of separation and increased visibility of the elements generated by a list was considered most useful for the integration of images of the Arma Christi into late medieval piety practice. In various depictions, access to the Arma and their function was created by the contrast of merging and separating. The applied strategies, however, varied, as can be seen in the following three examples. The Ulm 
woodcut showing the Man of Sorrows and the Arma Christi, the Arma Christi grid of the Omne Bonum manuscript in the British Library, and the illustrated Middle English poem "O Vernicle," are related to texts that integrated the images in the functional context. As such, the combinations of text and image shed light on the potential regarding the engagement of the recipient obviously ascribed to the enumerating form. Whereas the first two works, the woodcut from Ulm and the Arma Christi grid, are combined with an indulgence text, ${ }^{27}$ the "O Vernicle" is a poem enumerating the Arma Christi.

The single-leaf woodcut made in Ulm in approx. 1470-1485, ${ }^{28}$ (Fig. 12.4) shows structural similarity to the image in the Prayer Book of Bonne of Luxembourg. In both pictures, the body of Christ forms the nucleus and is surrounded by the other items, which are represented on a much smaller scale. But while the Arma in the manuscript are neatly arranged next to the side wound and give an impression of clarity and a certain order, the small individual pictures in the woodcut remain scattered over the page, their positions arbitrary and interchangeable. Arrangement in purposeful disorder, as found in the Ulm print, is a frequently encountered characteristic of Arma Christi representations. Robert Suckale has acknowledged this interplay between overview and disorder as a peculiar benefit for meditation. For him, the simultaneous conception, with everything synchronously juxtaposed and a clearly emphasized center, offers an outset to the observation but no end and no defined "lines of sight" ("Blickbahnen") either. This arrangement aligned with the abundance of the Arma would create a high degree of repeatability without being exhaustive (Suckale 2003, 36). Lisa Cooper and Andrea Denny-Brown follow Suckale's ideas when they describe the Arma Christi as a "devotional image cluster" that generates meaning through the sheer number of collected objects and their cultural significance $(2014 b, 1)$. Marius Rimmele also has taken the disorder of the Arma as a vantage point to reflect on the meaningful processes of pictorial and cognitive combination. Rimmele stressed the activation of the viewer, describing how he or she becomes a co-author when looking at the Arma and drawing individual and associative connections between the objects themselves and between them and the body of Christ (Rimmele 2010, 227-228).

Indeed, the additional value of the Arma Christi depictions arises from the individual elements, which offer a range of possibilities to create meaning (Rimmele 2010, 228) and thus succeed the functional level of 


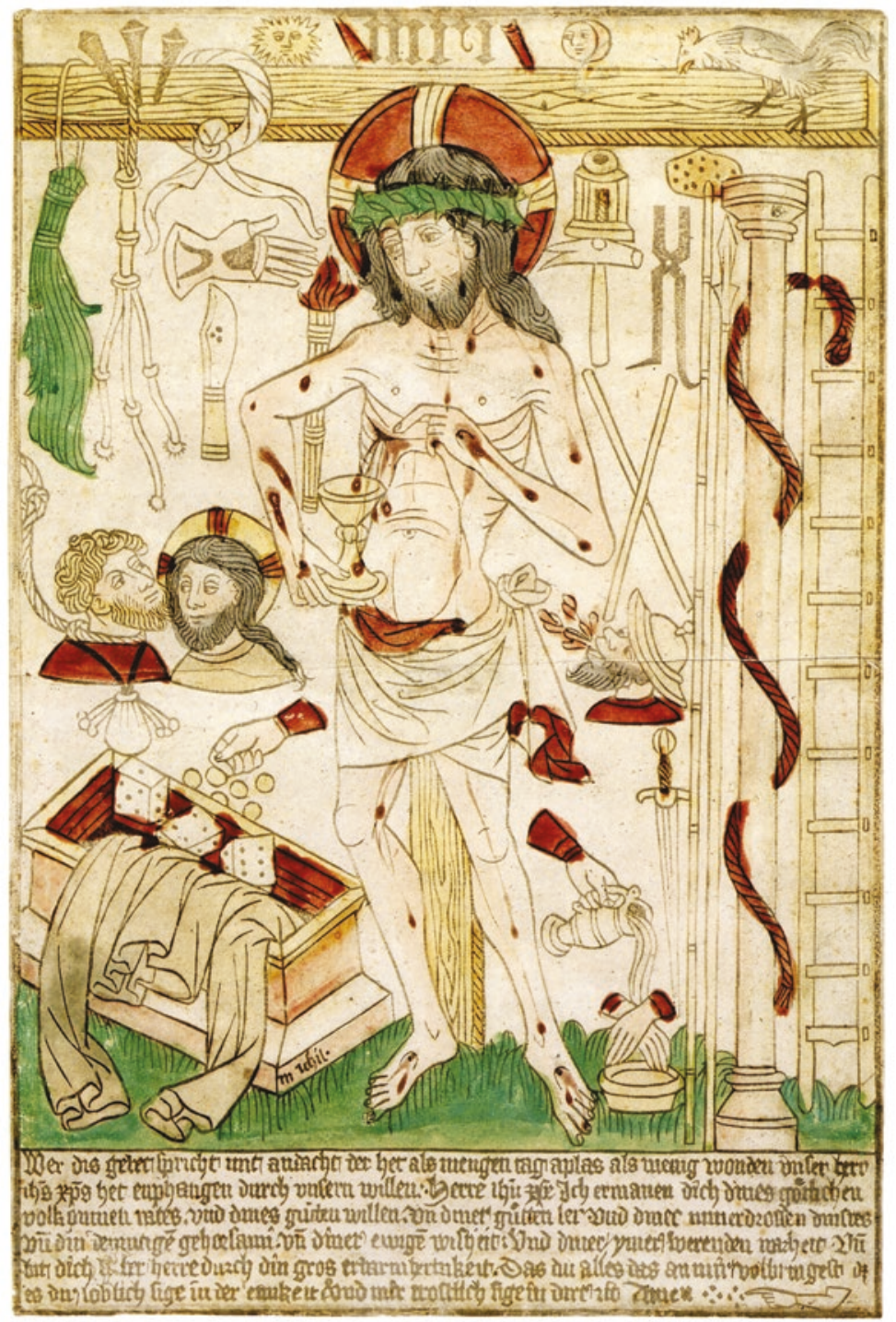

Fig. 12.4 Man of Sorrows with the Arma Christi, single-sheet woodcut, ca. 1470-1485, Germanisches Nationalmuseum, Nuremberg, Inv. No. H 9, image credits: Germanisches Nationalmuseum, Nuremberg 
mnemonic aids recalling the Passion. The basic idea, however, is not about generating a collective sum of meaning from all the parts and their respective concrete arrangement, but rather about recognizing the productivity of each distinct unit. In the Ulm woodcut, the unit is used purposefully to stimulate the viewer's attention in devotion. This strategy becomes clear when reading the text below the picture. Here, the prayer granting indulgence is introduced by a set of instructions: "Wer dis gebet spricht mit andacht der het als mengen tag aplas als menig wonden vnser herr / ihesus christus het enphangen durch vnsern willen" ("Whosoever speaks this prayer devoutly will receive as many days of indulgence as our Lord Jesus Christ suffered wounds for our sakes"). ${ }^{29}$ But the viewers of the print are called upon to not only say the prayer for indulgence but also, if they wish to know the outcome of their actions, to look closely at the picture, ponder the wounds of Christ, and deduce their number.

"Wounds" not only mean the body's physical injuries here, but also those actions that caused inner pain such as the mockery of spitting or Pilate washing his hands of guilt. The Man of Sorrows motif, which is often combined with the Arma, serves as a point of reference for the smaller pictures arranged around it, but the actual relationship between instrument and wound must first be established by the viewer during his or her devotional contemplation and meditation. Through an enumeration of the Arma, Christ's suffering is broken down into its parts and laid out with all its aspects visible to the viewer.

The depiction of the Arma on fol. 15r of the Omne Bonum manuscript $^{30}$ (approx. 1360-1375; Fig. 12.5) is also based on the effect of separation. The image on the $45.5 \times 31 \mathrm{~cm}$ page is a regular grid of 5 fields $\times 8$ fields. Like in a typesetting box, each instrument of the Passion is placed inside its own field of the same size, only the crucifixion and, below, the resurrection being exceptions and occupying compartments twice as large. Apart from the last line, there is a small text space underneath each box, in which an inscription names the presented object. ${ }^{31}$ The placement of the objects in the individual fields does not reveal any systematic order, but as in the Man of Sorrows woodcut and the Prayer Book of Bonne, the central vertical axis is accentuated. Here, the body of Christ appears in various forms in the grid's central column, evoked either directly or indirectly through a reference. Read from top to bottom, this time a chronological order is indicated: the series begins with the Host in the chalice (the Last Supper), followed by the spitting (first mockery of Christ), the face of 


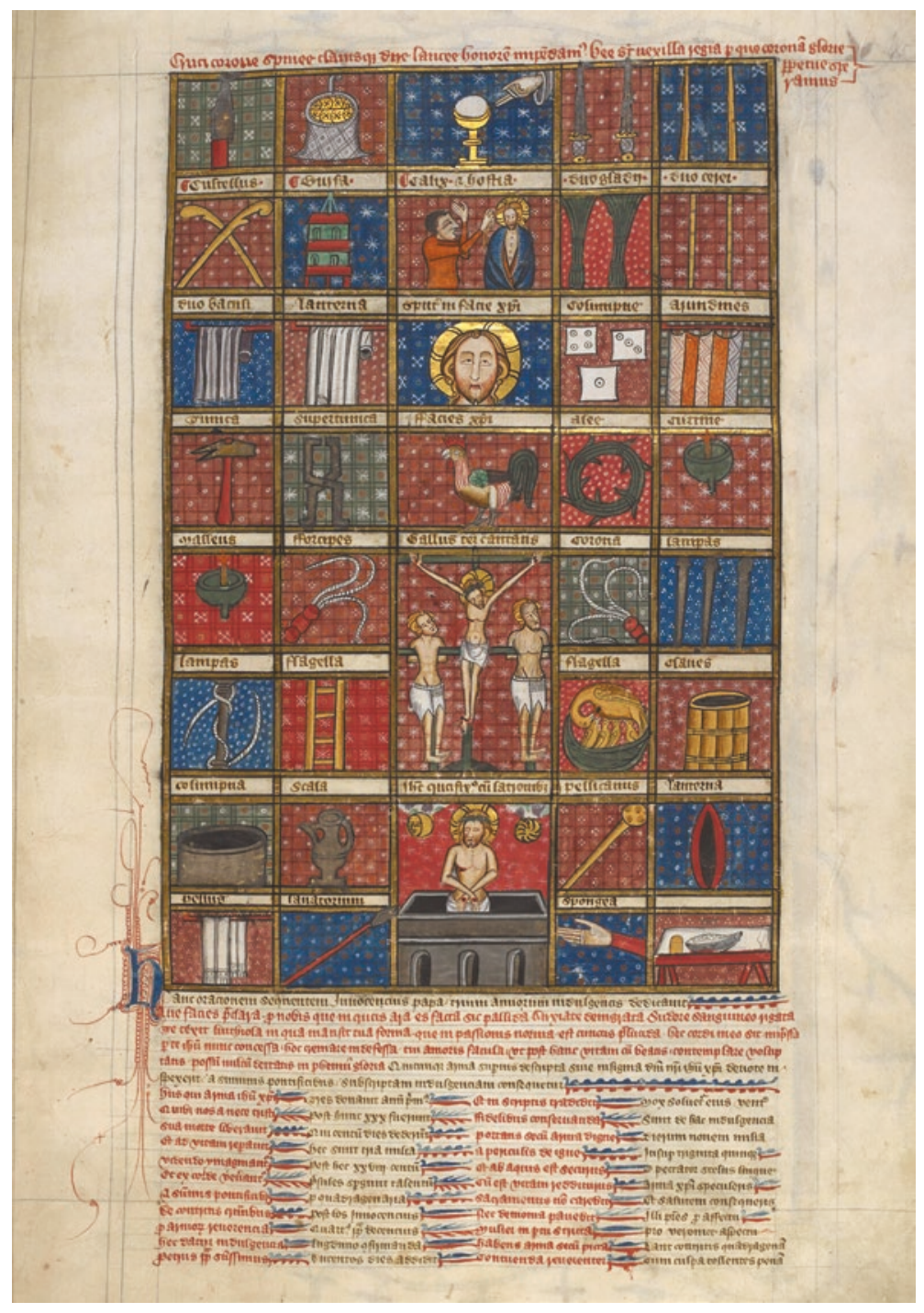

Fig. 12.5 Omne Bonum manuscript, England (London?), around 1360-1375, British Library, London, Royal MS 6 E VI/1, fol. 15r, (C) The British Library Board 
Christ as it appeared on the Veil of Veronica (bearing of the cross), the crucifixion, and finally the resurrection. Rather irritatingly, the sequence is interrupted by the cock of Peter's denial, which is positioned between Christ's face and the crucifixion and thus not only interferes with the chronological order but also severely disrupts the series of Christ's manifestations. The rooster seems to have been inserted as a deliberate break, as the side wound can also be found in the grid. Its placement in the central column would have been a logical consequence, but instead it is found in the penultimate field of the fifth column.

As in the single-sheet print, there is also an indulgence text written below the Arma Christi grid. ${ }^{32}$ The prayer "Ave facies praeclara" written in red ink is preceded by a note in brown ink indicating that, according to Pope Innocentius, the prayer would bring three years of indulgences. The prayer text is followed, again in brown ink, by a reference to the Arma grid above: "Quicumque arma superius descripta sive insignia domini nostri iesu christi devote inspexerit, a summis pontificibus subscriptam indulgenciam consequetur" ("Whoever devotedly contemplates the Arma, that is the insignia of Our Lord Jesus Christ, depicted above, will obtain the indulgence from the supreme pontiffs spelled out below"). ${ }^{33}$

Finally, the next and last paragraph on the page mentions the indulgences granted by various popes. Unlike the previous section, this text does not run across the full width of the text space but forms four columns, written alternately in red and brown ink and separated by red-blue filling. Thus, the enumerating verses become discernible in a tabular listlike appearance, although the entries are not made line by line. Instead, the verse pattern is blended with the list in form and content with the verses of the rhyming text going from top to bottom in each column. The lower sections' layout thus repeats what has already been observed in the grid: a visual ordering structure is created, but the content stored in it undermines this same structure by following its own formal rules and principles. Through this aesthetic inversion, an intriguing moment of irritation arises, which keeps the reader-viewer focused and probably motivates him or her to engage even more with the contents of the page. Yet, the text is also revealing as to the dynamics evolving between text and image, for the expression devote inspexerit together with the reference to the Arma Christi shown above (superius descripta) refers to the visual aspect of contemplation. As each item is given its own space in the list-grid, devotional contemplation could be dedicated either individually to one 
compartment at a time or could be continued successively from field to field and thus be extended in time. ${ }^{34}$

\section{Organizing Visual Perception}

From this type of visual organization, in which the grid provides a formal order, albeit one that is undermined by the disorderly placement of objects within the grid, a tension unfolds between the cohesion of the whole and the separation of the parts. The grid provides for both and thus acquires an ambivalent functionality also to be found in other representations of the Arma Christi as well as other enumerating motifs. This ambivalence is substantial for the list, which must always be accessible as a whole and in its parts at the same time. As mentioned above, a list is defined by its structure. The functionality of a list cannot be guaranteed if its elements are not recognizable, specific, and distinct. This very aspect of distinction, however, also requires a visible merging that marks each object as belonging to the list. ${ }^{35}$ The challenge of establishing visual or content-related coherence is less obvious in images such as the Man of Sorrows woodcut from Ulm or the Omne Bonum grid, as the space of the picture and its boundaries are clearly defined. However, if the Arma Christi are part of a visual program in which they are combined with other motifs, perhaps even other enumerations, the set must be recognizable as such. In the tropaion motif discussed above, for example, the elements appear as a group because of their proximity: they are clustered and overlap each other in an agglomeration. And in the Prayer Book of Bonne, a visual reflection on enumeration already unfolded through the aspects of demarcation and belonging. There, as in the Omne Bonum manuscript (but elsewhere as well), a frame was employed to visually consolidate the list. Both examples show how differently the artists made use of framing devices. While in the Bonnemanuscript only one item is singled out by the frame, each of the Arma is separated in the Omne Bonum grid. And just like in the prayer book, the frame in the Omne Bonum is deeply intertwined with the aesthetics of enumeration, too. Firstly, the division between the Arma and the narrative representations also integrated into the grid is made in a very subtle way. The crucifixion and resurrection are not represented by the cross and the sarcophagus, but by the Man of Sorrows in the open coffin and the crucifixion scene, in which Christ is joined by the two thieves, whose addition to the Arma would be more than unusual in visual art. Unlike the pictures of the instruments of the Passion, both representations occupy 
double spaces in the grid and thus stand out from the enumeration of the Arma. ${ }^{36}$ In addition, this skillful ordering principle of the grid engages the beholder in its own way as the attention is directed to the structure itself. Just as in the Bonne-manuscript, the meticulous design not only points to a thoughtful examination on the side of the artist, but is also used to make things more appealing, to hold the recipients' gaze on the page, and thus stimulate and focus contemplation. ${ }^{37}$ The innovative use of framing exhibited in the examples cited thus far is evidence of a thoughtful awareness of enumeratio as a pictorial device and shows how reflection on the characteristics and functionalities of a list played a crucial role in the design.

A summary-like overview, possible in the grid despite the separation of its elements, is denied to recipients of the "O Vernicle" rolls (Fig. 12.6). ${ }^{38}$ In these long, narrow strips of parchment, the individual Arma are arranged one below another; a linear viewing is the only option. The pictorial representations of the Arma are interwoven directly with the poem "O Vernicle," in which various Arma Christi are addressed one after another. It begins with the invocation of the vernicle, the Veil of Veronica, preceded by a pictorial representation of the Vera Icon. Pictures also introduce the respective verses in the following. They are placed either between the sections of text or to the left of them, resulting in a two-column view. Considering the handling of such a roll, sometimes over two meters long but only ten or fifteen centimeters wide, which was either unrolled completely or wound on sticks like the larger scrolls, a complete view of the Arma which captures Christ's sufferings simultaneously could not have been intended. ${ }^{39}$ Only the section being read would be viewable; the reader-viewers needed to move step-by-step through the successive units of the list. In contrast to the works considered so far, however, disorder does not seem to have been the decisive principle here.

Soon after the beginning, the arrangement of the individual verses is aligned with the chronology of events. In the edition by Nichols (2014) the veil is followed by the circumcision knife and the pelican, but then a chronologically consistent sequence starts with the thirty pieces of silver. The objects of betrayal and imprisonment are succeeded by the instruments of mockery. After this, the way to Calvary is evoked with footprints before the objects of crucifixion are mentioned: nails, the hammer, gall vessel, sponge, and lance. The sequence continues with the ladder of the deposition but then the order is interrupted by the spitting and carrying of the cross before ending with the tomb of Christ. 
Fig. 12.6 "O Vernicle" roll, England, early fifteenth century, Scottish Catholic Archives, Edinburgh, MS GB 0240, opening sequence, image credits: Scottish Catholic Archives, Edinburgh

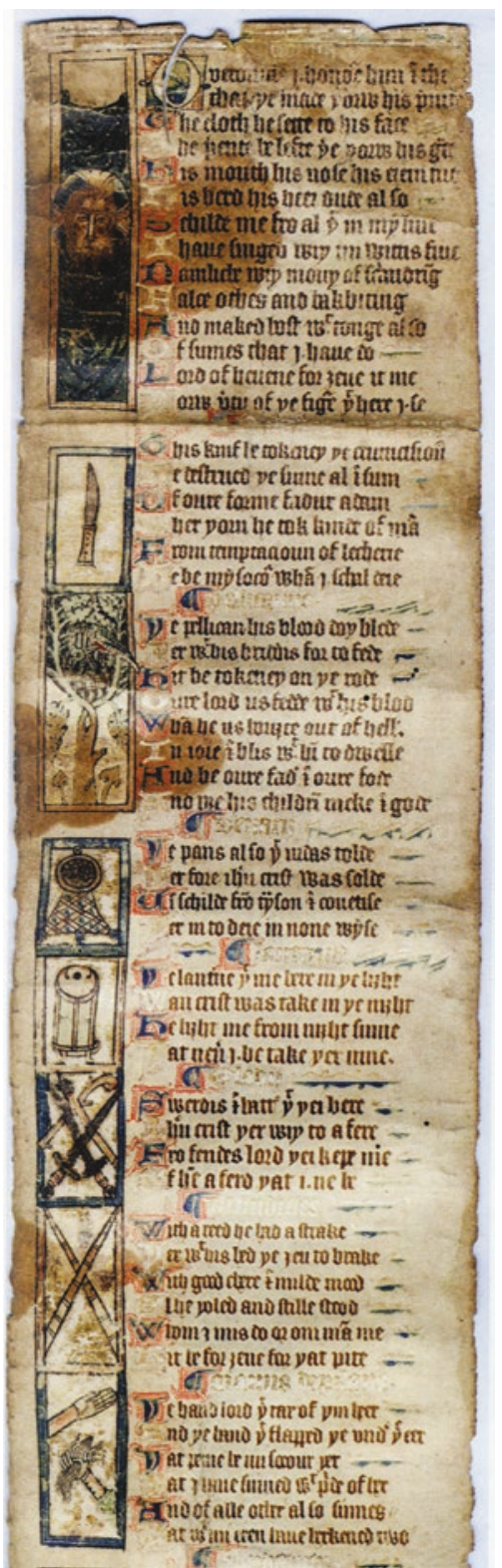


Although the vertical sequence is determined by the medium, the long and narrow parchment, it is evident that separation as a rhetorical form achieved by the principle of enumeration was known and purposefully used by the author to focus the reader-viewer's attention on the most crucial aspects. This already becomes clear in the first verse about the veil, which contains various enumerations itself. The theme is the face of Christ preserved in the Veil of Veronica. In the text, the face is initially divided into its parts: "His mouth, his nose, his eghen two, / His berde, his here dede al so." It is interesting to see how the functionality takes upon these individual parts binding them back together: "Schilde me fro all pat in my life" (11. 5-7). The speaker has sinned with all his five senses: "I haf synned with wittes fyve, / Namelich with mouth of sclaunderynge, / Fals othes and bakbytyng / And made bost with tong also / of synnes pat I haf i do / Lord of heuen, forgif it me / For pe figure pat I here se" (11. 8-14; Nichols 2014,354 ). As mentioned above, the poem is preceded by a picture of the face of Christ on the Veil of Veronica, and it is this very image that should now be contemplated while speaking the text. The listing of the details in the text changes the viewer's perception; after reading the verse, he or she sees not only the face as a whole but discerns its components. Of particular importance is the mouth, since the speaker enumerates his sins committed with speech, and the reader-viewer can use the image to relate to his own sinful behavior and its sensual aspects. The intermedial enumeration in "O Vernicle," therefore, proves itself a highly complex system that influences perception and guides contemplation.

Despite the diversity of visual possibilities inherent to the Arma-of which only a few could be explored here-it becomes clear how the pictorial motif of the Arma Christi is characterized by its enumerative nature per se. As in literature, the list emerges as a dispositif deployed strategically. ${ }^{40}$ Through the use of the enumeratio, the viewer's attention is redirected several times: not only do the objects contained in a list come into focus, the list itself and thus the enumeration also become subject of observation. "Lists can be self conscious, asking readers to think as much (or more) about the list as they do about the individual objects on it," as Katherine C. Little has pointed out $(2019,118)$ and, as shown, the visual design can force the perception and reflection of the list itself. An attentionshifting aestheticization of enumeration occurs, for example, in the tropaion motif when a cluster is created or when the impression is given that in the carefully laid out grid structure more attention is paid to the 
presentation of the contents than to their actual depiction, as in the Omne Bonum manuscript.

In the Arma Christi, as the examples have shown, the aesthetics of enumeration have always been combined productively with the function of representation. In the interaction of content and form, the motif of the Arma gained a particular effectiveness for the practice of piety. Representations of the instruments of the Passion demonstrate how, in the visual arts, enumeration is both a figure of artistic conception and a visual-rhetorical device of operational usefulness.

\section{Notes}

1. The Prayer Book of Bonne of Luxembourg, Duchess of Normandy, before 1349, Paris. New York, Metropolitan Museum, The Cloisters Collection, accession number 69.86 .

2. The wound caused the main interest in fol. $331 \mathrm{lr}$ so far, see for example Tammen 2006; Olsen 2015.

3. How access to salvation is granted through the wounds of the tormented body of Christ is described by Lentes 1995 .

4. "Nous monstre tres dous diex votre tres grant largesce. Quant vousistes pour nous souffrir tant de destresce" (Transcription and German translation from Tammen 2006, 96). The text is part of a known prayer about the wounds of Christ, see also the excerpt from the Book of Hours Paris, Bibliothèque de l'Arsenal, MS 570 (see Meyer 1901, 52, no. 9).

5. On the depiction of the birds see Vaurie 1971.

6. Here, the potential of the frame becomes evident. It creates a polarity of inside and outside, inclusion and exclusion, but can also be crossed. The artistic play with the frame and its possibilities on fol. 331 $\mathrm{r}$ can also be found in other images of the manuscript.

7. For a basic study of the Arma Christi in visual art, see Berliner 1955; Schiller 1968; Suckale 2003 [1977]; Rimmele 2010 examines questions of composition and the interrelations of the single elements. The materiality of the Arma is explored in the volume by Cooper and Denny-Brown 2014a.

8. Suckale 2003 [1977], 29, sees the reason for this diversity in the variety of relations facilitated by freely distributed elements and encouraging the imagination, but also in a desire to see the objects closely.

9. Suckale 2003 [1977], 27-29, also refers to the new combination of the elements for every new work.

10. Regarding visual rhetoric, an important impulse is provided in the volume by Knape 2007 .

11. Although art history has thoroughly examined the combination of motives and images in recent years, visual enumeration has rarely been considered 
to date. It can be assumed that the reason for this lies in the supposedly "simple form" of the list (see also von Contzen 2017a). Seminal works on the plurality of images are Ganz and Thürlemann 2010; Blum, Bogen, Ganz and Rimmele 2012; Thürlemann 2013.

12. Basic works with important impulses for the visual arts are Belknap 2000; Mainberger 2003; Jullien 2004a; Stäheli 201l; von Contzen 2017a, b.

13. For example, they are listed in the Acts of Thomas and the work of John Chrysostomos and other sources. See Edsall 2014a.

14. On the tropaion and tropaeum crucis as precursors to the Arma Christi, see Edsall 2014a, 42-43.

15. Utrecht Psalter, ninth century. Utrecht, Universiteitsbibliotheek, Ms. 32. The complete digitalization and an annotated edition can be found at https://bc.library.uu.nl/utrecht-psalter.html. Accessed 29 April 2020.

16. According to present-day numbering, Psalm 22.

17. The well-known words from Psalm 21, "O God, my God, look upon me: why hast thou forsaken me?" that Christ speaks on the cross, see Mt. 27,46 and $\mathrm{Mk} 15,34$.

18. Berliner 1955, 51-52, already presumes an apotropaic effect; see also Vizkelety 1995; Edsall 2014b explores the Arma Christi rolls regarding their possible use as amulets.

19. Booklet with scenes of the Passion and the Arma Christi, elephant ivory with painted and gilded leaves, ca. 1330-1340, Germany, $10.6 \times 6 \mathrm{~cm}$. London, Victoria \& Albert Museum, Museum number 11-1872. http:// collections.vam.ac.uk/item/O92726/devotional-booklet-devotionalbooklet-unknown/. Accessed 13 April 2020.

20. This is probably a reference to the first mocking of Christ, during which he is spat upon. The spitting is already cited as part of the Arma in early Christian sources (see examples in Edsall 2014a).

21. The soldiers played dice for Christ's robe beneath the cross.

22. Berliner $1955,51-52$, already drew attention to this aspect. He recognized a meaning in the Arma pictures that exceeds the purpose of remembering the stations of the Passion and presumes an apotropaic function in beholding the Arma.

23. The aspect of materiality was already addressed by Berliner 1955; Cooper and Denny-Brown 2014a, focused on this aspect as well.

24. Images grouping the Arma around the Man of Sorrows or focusing on the side wound open a bifocal perspective, whereby the viewer's gaze connects the objects with the Body of Christ through proximity.

25. "Crusoe's list removes things from concrete contextualized relationships and encloses them in a zone of heightened visibility" (Schmidgen 2001, 21). 
26. For the problems of interpreting a list and deviating its function from its elements see Mainberger 2003, 18-20.

27. On the Arma Christi in the context of indulgences, see Lewis 1992; Vizkelety 1995.

28. Signed "Michil," $41.4 \times 27.6 \mathrm{~cm}$. Nuremberg, Germanisches Nationalmuseum, Inv. No. H 9. See Parshall and Schoch 2005.

29. The subsequent prayer reads: "Herre ihesu Christe Jch ermanen dich dines gôtlichen volkomnen rates. Vnd dines guden willen. Vnd diner gůtten ler. Vnd diner unuerdrossen dinstes / Vnd diner demutigen gehorsami. Vnd diner ewigen wisheit: Vnd diner ymer werenden warheit. Vnd / bit dich $1[$ ie]ber herre durch din gros erbarmhertzigkeit. Das du alles das an mir volbringest dz. / es dir loblich sige in der ewikeit Vnd mir trostlich sige in dire zit Amen". Transcription from Parshall and Schoch 2005, 248.

30. James le Palmer: Omne Bonum, around 1360-1375, folio $45.5 \times 31 \mathrm{~cm}$, text space: $34.5 \times 19 \mathrm{~cm}$. London, British Library, Royal MS $6 \mathrm{E} \mathrm{VI/1}$. On the manuscript, which consists of a total of four parts bound in two volumes, see Sandler 1996. For fol. 15r, see vol. 1: 94 and vol. 2: 12.

31. A transcription of the inscriptions can be found in Sandler 1996, vol. $2,12$.

32. A complete transcription with a German translation is provided by Zimmermann 1997.

33. Transcription and translation from Sandler 1986, 230, no. 30, and Sandler 1996, vol.1, 163, no. 60 .

34. "Like the five wounds, the instruments of the Passion could be separated so that each received its own space on a page or roll and its own time within the devotion, extending visually and verbally the reader/viewer's contemplation of them" (Kamerick 2002, 173).

35. See also Belknap 2000, 36-37: "Lists must be examined from two opposing viewpoints: we look at the individual units that comprise a list (what does it hold?), and we look at the function or purpose of the list as a whole (how does it hold together?)".

36. Further divisions by grid-like structures are found in two prayer books associated with the Bohun family, the Oxford Book of Hours (Bodleian Library, MS Auct. D.4.4) and the Passional of Kunigunde (Prague, National Library of the Czech Republic, Sign. XIV A 17).

37. The significance of framing for enumerations and their visual disposition has been rarely examined; on the significance of framing in depictions of the Fifteen Signs before the Last Judgement, see Wagner 2016.

38. Ten roll manuscripts are known, all of them illustrated. In three of them, the poem "O Vernicle" is followed by a promise of indulgence. On the "O Vernicle" rolls, see Robbins 1939; Nichols 2009, 2014; Newhauser and Russel 2014; Edsall 2014b.

39. On the context of use, see Edsall 2014b. 
40. Jullien sees the practical effective power of the list as a specific dispositif made effective by strategic use of the relationships of antagonism and correlation to ensure the renewal of dynamics and their continuity $(2004 \mathrm{~b}, 12)$.

\section{REFERENCES}

Belknap, Robert E. 2000. The Literary List: A Survey of Its Uses and Deployments. Literary Imagination 2: 35-54.

Berliner, Rudolf. 1955. Arma Christi. Münchner Jabrbuch der bildenden Kunst 6: 35-152.

Blum, Gerd, Steffen Bogen, David Ganz, and Marius Rimmele, eds. 2012. Pendant Plus: Praktiken der Bildkombinatorik. Berlin: Reimer.

Cooper, Lisa H., and Andrea Denny-Brown, eds. 2014a. The Arma Christi in Medieval and Early Modern Material Culture: With a Critical Edition of ' $O$ Vernicle’. Abingdon: Taylor \& Francis Ltd.

. 2014b. Introduction: Arma Christi - The Material Culture of the Passion. In The Arma Christi in Medieval and Early Modern Material Culture: With a Critical Edition of 'O Vernicle', ed. Lisa H. Cooper and Andrea Denny-Brown, 1-20. Abingdon: Taylor \& Francis Ltd.

Defoe, Daniel. 1985 [1719]. Robinson Crusoe. London: Penguin.

Edsall, Mary Agnes. 2014a. The Arma Christi Before the Arma Christi: Rhetorics of the Passion in Late Antiquity and the Early Middle Ages. In The Arma Christi in Medieval and Early Modern Material Culture: With a Critical Edition of ' $O$ Vernicle', ed. Lisa H. Cooper and Andrea Denny-Brown, 21-51. Abingdon: Taylor \& Francis Ltd.

- 2014b. Arma Christi Rolls or Textual Amulets? The Narrow Roll Format Manuscripts of "O Vernicle". Magic, Ritual, and Witchcraft 9 (2): 178-209.

Ganz, David, and Felix Thürlemann, eds. 2010. Das Bild im Plural: Mehrteilige Bildformen zwischen Mittelalter und Gegenwart. Berlin: Reimer.

Jullien, François, ed. 2004a. Die Kunst, Listen zu erstellen. Berlin: Merve Verlag.

- 2004b. Einleitung. In Die Kunst, Listen zu erstellen, ed. François Jullien, 7-14. Berlin: Merve Verlag.

Kamerick, Kathleen. 2002. Popular Piety and Art in the Late Middle Ages: Image Worship and Idolatry in England 1350-1500. New York/Basingstoke: Palgrave MacMillan.

Knape, Joachim, ed. 2007. Bildrhetorik. Baden-Baden: Verlag Valentin Koerner.

Lentes, Thomas. 1995. Nur der geöffnete Körper schafft Heil: Das Bild als Verdoppelung des Körpers. In Glaube Liebe Hoffnung Tod (Exhibition Catalogue), ed. Christoph Geissmar-Brandi and Eleonora Louis, 152-155. Vienna: Kunsthalle Wien. 
Lermack, Anette. 2008. Spiritual Pilgrimage in the Psalter of Bonne of Luxembourg. In The Art, Science, and Technology of Medieval Travel, ed. Robert Bork and Andrea Kann, 97-111. Abingdon: Routledge.

Lewis, Flora. 1992. Rewarding Devotion: Indulgences and the Promotion of Images. In The Church and the Arts, ed. Diana Wood, 179-194. Oxford: Blackwell.

Little, Katherine C. 2019. The Politics of Lists. Exemplaria 31 (2): 117-128.

Mainberger, Sabine. 2003. Die Kunst des Aufzählens: Elemente zu einer Poetik des Enumerativen. Berlin/New York: De Gruyter.

Meyer, Paul. 1901. Prières et poésies religieuses: Tirées d'un manuscrit lorrain (Arsenal 570). Bulletin de la Société des anciens textes français 27: 43-81.

Newhauser, Richard G., and Arthur J. Russel. 2014. Mapping Virtual Pilgrimage in an Early Fifteenth-Century Arma Christi Roll. In The Arma Christi in Medieval and Early Modern Material Culture: With a Critical Edition of ' $O$ Vernicle', ed. Lisa H. Cooper and Andrea Denny-Brown, 83-112. Abingdon: Taylor \& Francis Ltd.

Nichols, Ann Eljenholm. 2009. O Vernicle: Illustrations of an Arma Christi Poem. In Tributes to Kathleen L. Scott: English Medieval Manuscripts: Readers, Makers and Illuminators, ed. Marlene Villalobos Hennessy, 139-169. Turnhout: Harvey Miller Publishers.

- 2014. O Vernicle: A Critical Edition. In The Arma Christi in Medieval and Early Modern Material Culture: With a Critical Edition of 'O Vernicle', ed. Lisa H. Cooper and Andrea Denny-Brown, 308-392. Abingdon: Taylor and Francis Ltd.

Olsen, Vibeke. 2015. Penetrating the Void: Picturing the Wound in Christ's Side as a Performative Space. In Wounds and Wound Repair in Medieval Culture, ed. Kelly DeVries and Larissa Tracy, 313-339. Leiden/Boston: Brill.

Parshall, Peter W., and Rainer Schoch. 2005. Die Anfänge der europäischen Druckgraphik: Holzschnitte des 15. Jahrhunderts und ihr Gebrauch (Exhibition Catalogue). Nürnberg: Germanisches Nationalmuseum.

Rimmele, Marius. 2010. Geordnete Unordnung: Zur Bedeutungsstiftung in Zusammenstellungen der Arma Christi. In Das Bild im Plural: Mehrteilige Bildformen zwischen Mittelalter und Gegenwart, ed. David Ganz and Felix Thürlemann, 219-242. Berlin: Reimer.

Robbins, Rossell Hope. 1939. The “Arma Christi” Rolls. The Modern Language Review 34 (3): 415-421.

Sandler, Lucy Freeman. 1986. Face to Face with God: A Pictorial Image of the Beatific Vision. In England in the Fourteenth Century: Proceedings of the 1985 Harlaxton Symposium, ed. W. Mark Ormrod, 224-235. Woodbridge: Boydell and Brewer.

- 1996. Omne Bonum: A Fourteenth-Century Encyclopedia of Universal Knowledge: British Library MSS Royal 6 E VI - 6 E VII, 2 vols. London: Harvey Miller. 
Schiller, Gertrud. 1968. Ikonographie der christlichen Kunst, vol. 2: Die Passion Jesu Christi. Gütersloh: Gütersloher Verlagshaus Mohn.

Schmidgen, Wolfgang. 2001. Robinson Crusoe, Enumeration, and the Mercantile Fetish. Eighteenth-Century Studies 35 (1): 19-39.

Stäheli, Urs. 2011. Das Soziale als Liste: Zur Epistemologie der ANT. In Die Wiederkehr der Dinge, ed. Friedrich Balke, Maria Muhle, and Antonia von Schöning, 83-101. Berlin: Kulturverlag Kadmos.

Suckale, Robert. 2003 [1977]. Arma Christi: Überlegungen zur Zeichenhaftigkeit mittelalterlicher Andachtsbilder. In Stil und Funktion: Ausgewäblte Schriften zur Kunst des Mittelalters, ed. Peter Schmidt, Robert Suckale and Gregor Wedekind, 15-58. Munich: Deutscher Kunstverlag.

Tammen, Silke. 2006. Blick und Wunde - Blick und Form: Zur Deutungsproblematik der Seitenwunde Christi in der spätmittelalterlichen Buchmalerei. In Bild und Körper im Mittelalter, ed. Katrin Kärcher, Kristin Marek, Raphaèle Preisinger, and Marius Rimmele, 44-85. Munich: Wilhelm Fink Verlag.

Thürlemann, Felix. 2013. Mehr als ein Bild: Für eine Kunstgeschichte des "byperimage”. Munich: Wilhelm Fink Verlag.

Vaurie, Charles. February 1971. Birds in the Prayer Book of Bonne of Luxembourg. The Metropolitan Museum of Art Bulletin 29 (6): 279-283.

Vizkelety, András. 1995. Ein Beispiel zur Funktion und Praxis der Arma-ChristiAndacht im Spätmittelalter. In Sô wold ich in fröiden singen: Festgabe für Anthonius H. Touber zum 65. Geburtstag, ed. Helmut Birkhan and Carla Dauven-van Knippenberg, 521-530. Amsterdam: Brill.

von Contzen, Eva. 2017a. Grenzfälle des Erzählens: Die Liste als einfache Form. In Komplexität und Einfachbeit, ed. Albrecht Koschorke, 221-239. Stuttgart: Springer.

- 2017b. Die Affordanzen der Liste. Literaturwissenschaft und Linguistik 47: 317-326.

Wagner, Daniela. 2016. Die Fünfzehn Zeichen vor dem Jüngsten Gericht: Spätmittelalterliche Bildkonzepte für das Seelenheil. Berlin: Reimer.

Zimmermann, Andrea. 1997. Jesus Christus als "Schmerzensmann" in hoch- und spätmittelalterlichen Darstellungen der bildenden Kunst: Eine Analyse ibres Sinngehalts. PhD dissertation, University of Halle. Retrievable at: https://sundoc.bibliothek.uni-halle.de/diss-online/97/98H110/prom.pdf. Accessed 2 May 2020. 
Open Access This chapter is licensed under the terms of the Creative Commons Attribution 4.0 International License (http://creativecommons.org/licenses/ by $/ 4.0 /$ ), which permits use, sharing, adaptation, distribution and reproduction in any medium or format, as long as you give appropriate credit to the original author(s) and the source, provide a link to the Creative Commons licence and indicate if changes were made.

The images or other third party material in this chapter are included in the chapter's Creative Commons licence, unless indicated otherwise in a credit line to the material. If material is not included in the chapter's Creative Commons licence and your intended use is not permitted by statutory regulation or exceeds the permitted use, you will need to obtain permission directly from the copyright holder. 